\title{
Lithospheric structure across the Transantarctic Mountains constrained by an analysis of gravity and thermal structure
}

\author{
Audrey D. Huerta \\ Department of Geological Sciences, The Pennsylvania State University, University Park, PA 16801, USA (ahuerta@geosc.psu.edu)
}

\begin{abstract}
The Transantarctic Mountains demarcate the boundary between the highly extended lithosphere of the West Antarctic Rift System and the Proterozoic East Antarctic Craton. Although the last stage of relief development was in the Eocene, the TAM retain peak elevations in excess of $4500 \mathrm{~m}$. This combination of old age and high relief are difficult to reconcile, and the mechanism(s) responsible for uplift and support of this mountain range remain elusive and controversial. Recent seismic studies provide key constraints on the crustal structure. Here we constrain the lithospheric structure across this boundary by forward modeling of the gravity based on a density structure that reflects the thermal structure. Our results show that the observed very-long wavelength $(>500 \mathrm{~km})$ gravity anomaly can be modeled by a West Antarctic lithosphere $\sim 60 \mathrm{~km}$ thick, and an East Antarctic lithosphere $\sim 250 \mathrm{~km}$ thick. In addition, the gravity anomaly associated with the TAM can be modeled by including the thermal effects of heat producing elements concentrated in the crust.
\end{abstract}

Citation: A. D. Huerta (2007), Lithospheric structure across the Transantarctic Mountains constrained by an analysis of gravity and thermal structure, in Antarctica: A Keystone in a Changing World - Online Proceedings of the $10^{\text {th }}$ ISAES, edited by A. K. Cooper and C. R. Raymond et al., USGS Open-File Report 2007-1047, Short Research Paper 022, 4 p.; doi:10.3133/of2007-1047.srp022.

\section{Introduction}

Development of the Transantarctic Mountains (TAM) is related to the evolution of the adjacent West Antarctic Rift System (WARS), although the exact uplift mechanism(s) remain controversial and include flexure (Stern and ten Brink, 1989; ten Brink et al, 1997), necking (Chery et al., 1992; van der Beek et al., 1994), and collapse of a West Antarctic plateau (Studinger et. al., 2004; Huerta \& Harry, 2007; Bialas et al, in press). Extension of the WARS region must have raised temperatures of the lithosphere, and may have warmed the adjacent TAM lithosphere (Behrendt 1999; Behrendt et al., 1991). ten Brink and Stern (1992) propose that heat conducted from the WARS lithosphre warmed the mantle underlying the TAM and is responsible for much of the uplift of the TAM. Seismic investigations are consistent with this hypothesis, in that they reveal anomalously slow mantle under the Ross Sea that may extend under the TAM (Bannister et al, 2000; Danesi and Morelli, 2001; and Ritzwoller et al, 2001).

Additional seismic studies reveal that at $\sim 100 \mathrm{~km}$ depth shear wave velocities drop precipitously from $\sim 4.6$ $\mathrm{km} / \mathrm{s}$ in East Antarctica to $\sim 4.2 \mathrm{~km} / \mathrm{s}$ under the TAM (Lawrence et al., 2006b). Also surface wave (Lawrence et al, 2006c) and body wave tomography (Watson et al., 2006) observed low velocities beneath the Ross Sea, moderate velocities beneath the TAM, and high velocities beneath EA.

Prior to recent seismic results, attempts to model the mechanisms responsible for the uplift and support of the TAM relied on forward models of gravity anomalies that were unconstrained by information on the depth to moho. However, results of a recent broadband seismic and aerogeophysical experiment provide key constraints on the structure of the crustal and upper mantle of the TAM and adjacent East Antarctic craton and West Antarctic
Rift System (Fig. 1; Lawrence et al, 2006a; 2006b; 2006c Watson et al., 2006). Results of Lawrence (2006b) constrain the thickness of the crust in the region and reveal a $5 \pm 2 \mathrm{~km}$ crustal root beneath the TAM as had been suggested by gravity models (Studinger, et al., 2004; 2006).

Forward gravity models across the region indicate that the observed crustal root is insufficient to account for the elevation and gravity signature of the TAM, and Lawrence (2006b) matched the observed gravity by incorporating low-density mantle under the TAM (Fig. 1).

While there is a growing body of literature indicating that extension of the West Antarctic lithosphere has resulted in anomalously warm mantle under the Ross Sea and across the Transantarctic Mountains, however, details on the structure of the lithosphere remain undetermined. Here I explore constraining the lithospheric structure across the TAM region by use of forward gravity models based on density that directly reflects variations in the geometry and thermal structure of the crust and mantle. Prevous studies have shown the power of this technique in determining the lithospheric thickness (Fullea et al. 2007).

\section{Methods}

I used an iterative technique to constrain the lithospheric structure:

1) Estimate initial lithospheric thicknesses of WARS, TAM and East Antarctica, and for crustal heat production rates.

2) Determine the thermal structure of the cross section to a depth equal to the maximum lithospheric thickness.

3) Calculate the density structure of the cross section

4) Calculate the free air anomaly.

I repeated steps 1-4 until an acceptable result for the calculated free air anomaly is achieved. 
I use topography, crustal thickness, bathymetry, ice thickness, sedimentary thicknesses, and gravity anomaly determined by Lawrence et al (2006b). Ice density (920 $\left.\mathrm{kg} / \mathrm{m}^{3}\right)$ water density $\left(1030 \mathrm{~km} / \mathrm{m}^{3}\right)$, sediment dentity $\left(2400 \mathrm{~kg} / \mathrm{m}^{3}\right)$ are all assumed to be constant. Crustal and mantle velocity each vary as a function of temperature and pressure (Table 1).

\begin{tabular}{|c|c|c|}
\hline Input Parameters & Crust & Mantle \\
\hline $\begin{array}{l}\text { Thermal Conductivity, } \\
\mathrm{W} \mathrm{m}-1^{\circ} \mathrm{C}-1\end{array}$ & 2.5 & 3.4 \\
\hline $\begin{array}{l}\text { Specific heat, J kg-1 } \\
{ }^{\circ} \mathrm{C}-1\end{array}$ & 875 & 1250 \\
\hline $\begin{array}{l}\text { Coefficient of thermal } \\
\text { expansion, }{ }^{\circ} \mathrm{C}-1\end{array}$ & $3.5 \times 10-5$ & $3.5 \times 10-5$ \\
\hline Compressibility, Pa-1 & $\begin{array}{l}9.0 \times 10- \\
11\end{array}$ & $3.0 \times 10-11$ \\
\hline Nominal Density* & $\begin{array}{l}2775 \\
\mathrm{~kg} / \mathrm{m} 3\end{array}$ & $3200 \mathrm{~kg} / \mathrm{m} 3$ \\
\hline Output Parameters & $\begin{array}{c}\text { East } \\
\text { Antarctica }\end{array}$ & $\begin{array}{c}\text { TAM, and West } \\
\text { Antarctica }\end{array}$ \\
\hline $\begin{array}{l}\text { Crustal heat } \\
\text { production, } \mu \mathrm{W} \mathrm{m}{ }^{-3}\end{array}$ & 1.25 & 2.5 \\
\hline $\begin{array}{l}\text { Lithospheric thickness, } \\
\mathrm{km}\end{array}$ & 250 & 60 \\
\hline
\end{tabular}

Table 1. Model parameters

The thermal structure is calculated based on the steady-state solution of the 2-d heat transfer equation

$$
0=\kappa\left(\frac{\partial^{2} T}{\partial x^{2}}+\frac{\partial^{2} T}{\partial y^{2}}+\frac{A(x, y)}{K}\right)
$$

where $\kappa$ is the thermal diffusivity $\left(10^{-6} \mathrm{~m}^{2} / \mathrm{s}\right), A$ is heat production rate, and $K$ is thermal conductivity, with boundary conditions of $T=0^{\circ} \mathrm{C}$ at the top of the model and $T=1300^{\circ} \mathrm{C}$ at the lithosphere/asthenosphere boundary (see Table 1 for other parameter values).

Simple, back-of-the envelope calculations provide a starting-point for estimating the lithospheric structure. The observed gravity difference between East Antarctica and WARS is $\sim 80 \mathrm{mGal}$. This long-wavelength difference is primarily due to two factors 1) lateral variations in the thickness of the crust and 2) lateral variations in density of the mantle. The gravity difference due to the change in thickness of the crust can be approximated by the effect of an infinite horizontal slab (Telford et al, 1990) of mantle replacing crust given by

$$
g=2 \pi \gamma \Delta \rho t
$$

where $\gamma=$ universal gravitational constant $=6.672 \times 10^{-11}$ $\mathrm{Nm}^{2} / \mathrm{kg}^{2}$,

$\Delta \rho=$ difference in density $=(2800-3200) \mathrm{kg} / \mathrm{m}^{3}=400$ $\mathrm{kg} / \mathrm{m}^{3}$, and

$t=$ difference in crustal thickness $=5000 \mathrm{~m}$
This caclucation yields $g=270 \mathrm{mGal}$ higher gravity expected in WARS than EA due to thinner crust.
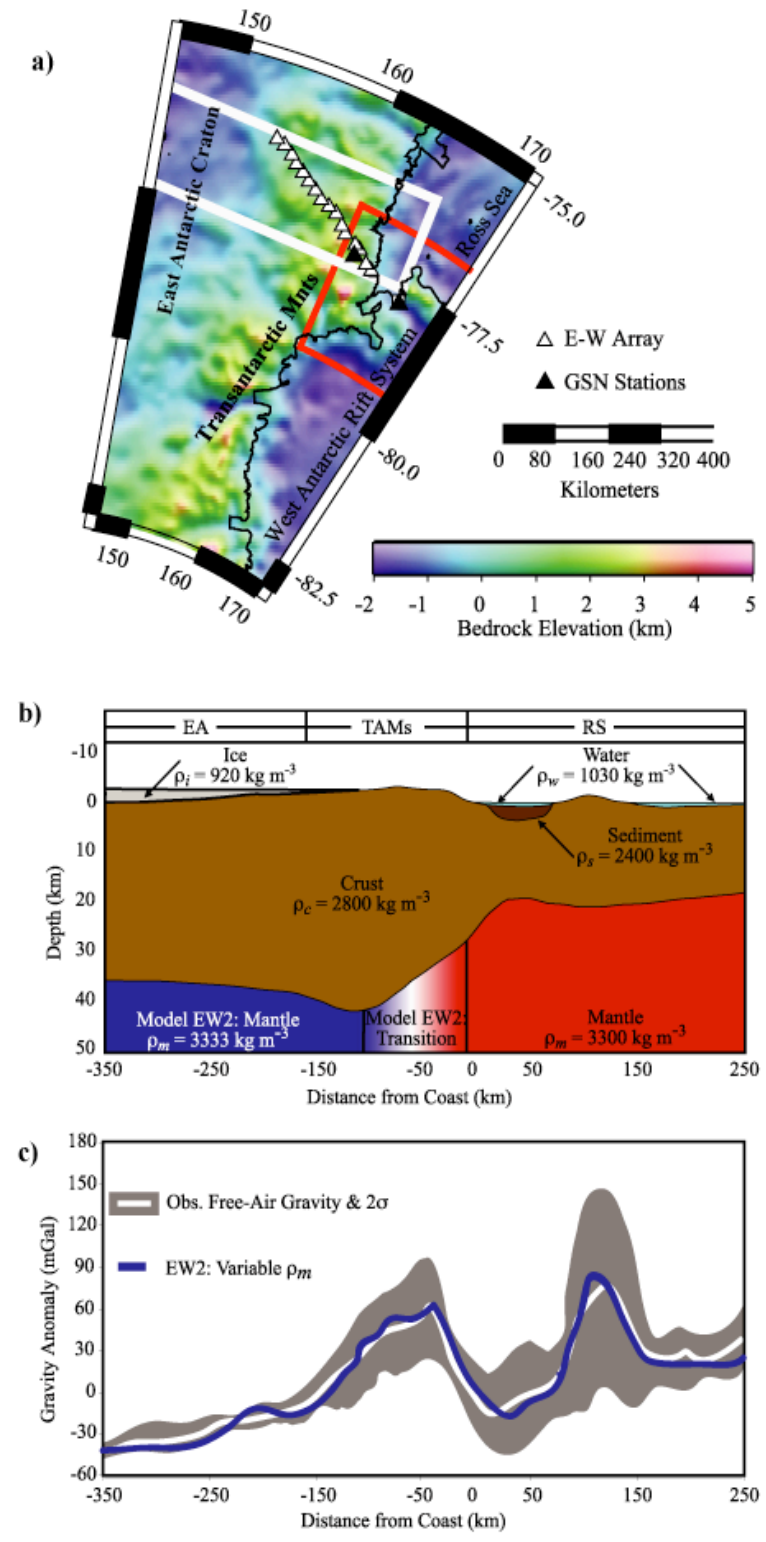

Figure 1. (a) Map of seismic array on shaded relief bedrock topography from BEDMAP (Lythe et al, 2001). The white box shows airborne geophysics surveys flown between 1999 and 2001 (Blankenship et al., 2001; Holt, 2001). The red box outlines the region where other geophysical data were supplemented (ADGRAV, http://www.marine-geo.org/antarctic/gravity2004). (b) Two-dimensional density model of the transect. (c) Theoretical free-air gravity (blue) and observed free-air gravity with 2-sigma (white and gray). Bathymetry, topography, bedrock elevations, moho topography after Lawrence, et al, (2006b). 
However, the gravity signal in WARS is only $90 \mathrm{mGal}$ higher than in EA, leaving a deficit of 180 mGal. Lowerdensity mantle must be the cause of the "missing" 180 mGal. To estimate the thickness of the low density mantle, I again use the infinite horizontal slab and assume a density difference of $30 \mathrm{~kg} / \mathrm{m}^{3}$, resulting in an estimate of at least $140 \mathrm{~km}$ less high density mantle in WARS than in EA.

In addition to the thermal consequences of thinner lithosphere, I also include the thermal impact of heat producing elements within the crust. Previous models of the WARS evolution inidicate that the crust of the TAM and WARS region is enriched in heat producing elements (Huerta \& Harry, 2007; Bialas et al, in press). Including the impact of radiogenic heat also affects the density structure of the lithosphere.

Thus, I begin with a geometry based on the observed crustal structure, estimated values for crustal heat production, and a lithospheric structure with the WARS lithosphere $140 \mathrm{~km}$ thinner than EA lithosphere. The density structure is then determined as a function of the calculated temperature and pressure.

Based on the density structure, gravity anomalies are calculated using the 2-1/2 D forward modeling techniques of Talwani et al. (1959) and Cady (1980) (Talwani Gravity Modeling Program developed by the GEON project team at the University of Texas at El Paso www.geongrid.org).

This procedure is repeated until an acceptable result for the calculated free air anomaly is achieved (Fig. 2).

\section{Modeled Lithospheric Structure}

The model that matches the regional free-air gravity (Figure 2, Table 1) has an East Antarctic lithospheric thickness of $250 \mathrm{~km}$ and a crustal heat production rate of $1.25 \mu \mathrm{W} / \mathrm{m}^{3}$, consistent with the cratonal nature of East Antarctica and heat flow estimates (Siegert \& Dowdeswell, 1996). The modeled thickness of the West Antarcic lithosphere is $60 \mathrm{~km}$, and the crustal heat production rate is $2.5 \mu \mathrm{W} / \mathrm{m}^{3}$, consistent with the highly extended nature of West Antarctica and extensional models (Cooper and Davey, 1985; Huerta \& Harry, 2007; Bialas et al., in press). A thin low-density $\left(2400 \mathrm{~kg} / \mathrm{m}^{3}\right)$ layer of Beacon sediments is included in the EA crust between -300 to $-125 \mathrm{~km}$ to improve the shortwavelength fit, in agreement with results from previous studies (Studinger, et al., 2004; ten Brink et al, 1997).

In West Antarctica, the combination of a thin lithosphere and moderate crustal heat production results in warm, low-density mantle to depths of $\sim 150 \mathrm{~km}$, while in East Antarctica the cold and thick lithosphere results in a high density crust and mantle. Across the TAM, the transition between the two lithospheres results in a transitional mantle density.

\section{Sensitivity Analysis}

The very-long-wavelength fit of the modeled gravity to the observed gravity is most dependant on the juxtaposition of the thick, cold lithosphere of East Antarctica with the thin, warm lithosphere of West Antarctica. For example, increasing the thickness of the West Antarctic lithosphere by $15 \mathrm{~km}$ increases the gravity by $\sim 150 \mathrm{mGal}$, far beyond the 2 -sigma variation in the observed gravity. The model fit across the TAM is also highly dependant on the inclusion of crustal heat production. For example, if heat production of the TAM/WARS crust is reduced by $0.5 \mu \mathrm{W} / \mathrm{m}^{3}$, the calculated gravity increases in the WARS region by $\sim 35$ $\mathrm{mGal}$, and increases in the TAM by $\sim 70 \mathrm{mGal}$, again well beyond the 2 -sigma varation in the observed gravity.
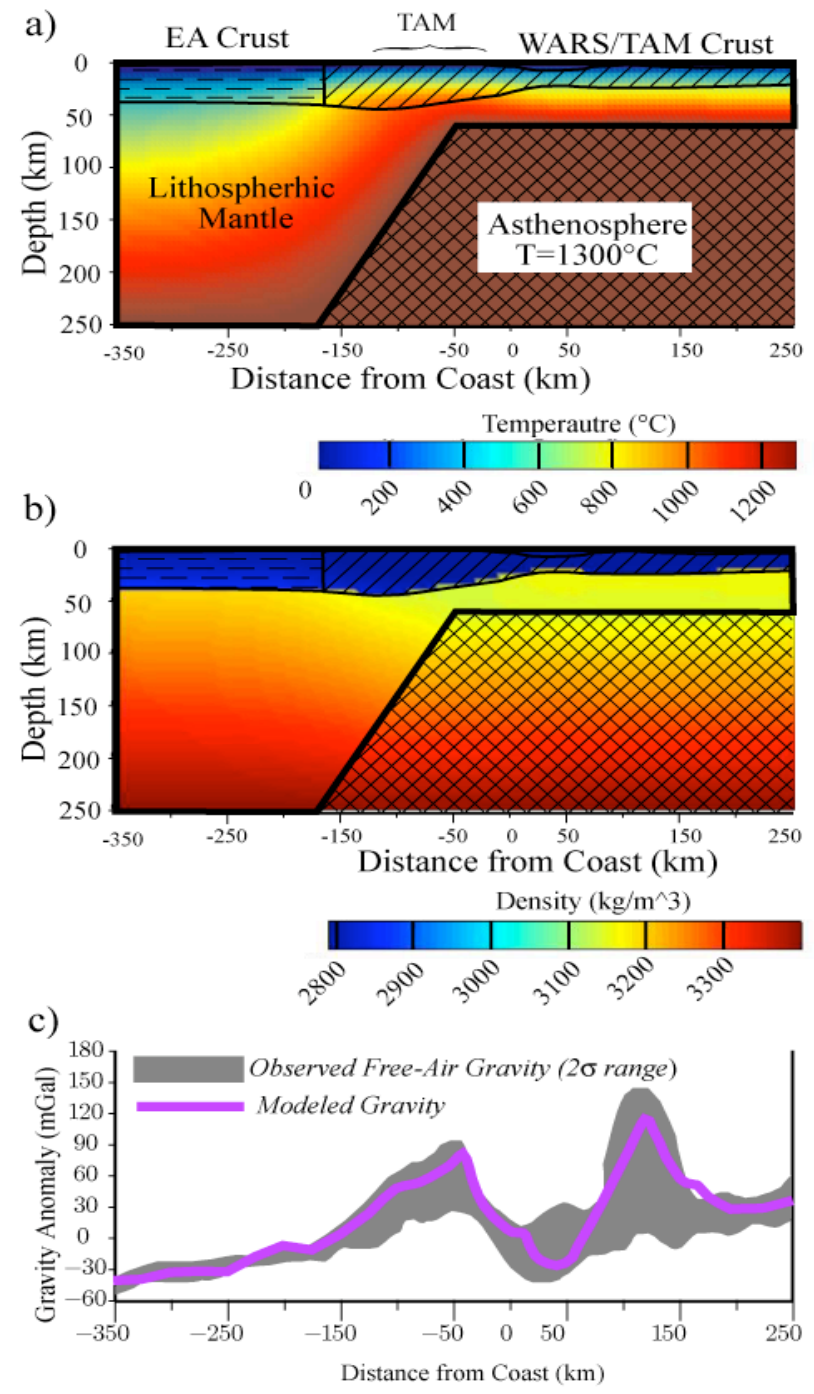

Figure 2. (a) 2-D thermal model. (b) 2-D density model (c) Calculated free-air gravity (pink) with 2-sigma variability of observed free-air gravity (gray).

\section{Discussion}

Recent seismic studies reveal the presence of lowvelocity material in the shallow mantle of the WARS/TAM region (Lawrence et al., 2006a; 2006b; 
Watson et al, 2006), however, this anomaly does not appear to extend deeper to the mantle discontinuities at $410 \mathrm{~km}$ and $660 \mathrm{~km}$ (Larson et al, 2006). This apparent conundrum is readily explained by the lithospheric structure presented here. Low density mantle is present at relatively shallow depths in the WARS/TAM region where warm asthenosphere rises beneath the thinned lithosphere. This low density mantle would have an associated velocity anomaly. However, at depth greater than $250 \mathrm{~km}$, mantle temperatures are continuous across the region, and there is no associated density or seismic anomaly.

\section{Summary}

Results of gravity modeling based on realistic density distribution provide constraints on the lithospheric structure of Transantarctic Mountains and surrounding regions. Model results yield a lithospheric thickness of 60 $\mathrm{km}$ for the Ross Sea region of the West Antarctic Rift System, and a lithospehric thickness of $\sim 250 \mathrm{~km}$ for the East Antarctic craton. These thicknesses are consistent with the tectonic setting of an extended region of West Antarctica and the cratonic lithosphere of East Antarctica. In addition, model results suggest that the necessary additional bouyant support of the TAM comes from radiogenic heat of the TAM crust.

Acknowledgements Thanks for helpful reviews by R. Bialas, J. Lawrence \& M. Studinger, and thanks to H. Stagg for editorial input.

\section{References:}

Bannister, S., R. K. Snieder, and M. L. Passier (2000), Shearwave velocities under the Transantarctic Mountains and the Terror Rift from surface wave inversion, Geophys. Res. Lett., 27, 281-284.

Behrendt, J. C. (1999), Crustal and lithospheric structure of the West Antarctic Rift System from geophysical investigations - a review, Global Planet. Change, 23, 25-44.

Behrendt, J. C., W. E. LeMasurier, A. K. Cooper, F. Tessensohn, A. Trehu, and D. Damaske (1991), Geophysical studies of the West Antarctic Rift System, Tectonics, 10(6), 1257-1273.

Bialas, R. W., W. R. Buck, M. Studinger, and P. G. Fitzgerald (in press), Plateau collapse model for the Transantarctic Mountains/West Antarctic Rift System: Insights from numerical experiments, Geology.

Blankenship, D. D., D. L. More, C. A. Finn, R. E. Bell, M. E. Peters, S. D. Kempf, S. M. Hodge, M. Studinger, J. C. Behrendt, and J. M. Brozena (2001), Geologic controls on the initiation of rapid basal motion for West Antarctic ice streams: a geophysical perspective including new airborne radar sounding and laser altimetry results, in The West Antarctic Ice Sheet: Behavior and Environment, Antarct. Res. Ser., vol. 77, edited by R. A. Bindschadler, pp 105-121, AGU, Washington, D.C.

Cady, J. W. (1980), Calculation of gravity and magnetic anomalies of finite-length right polygonal prisms, Geophysics, 45, 1507-1512

Chery J., F. Lucazeau, M. Daignieres, and J. P. Vilotte (1992), Large uplift of rift flanks: a genetic link with lithospheric rigidity?, Earth Planet Sci. Lett., 112, 195-211.

Cooper, A. K., and F. J. Davey (1985), Episodic rifting of Phanerozoic rocks in the Victoria land Basin, western Ross Sea, Antarctica, Science 229 (4718), 1085-1087.

Danesi, S., and A. Morelli (2001), Structure of the upper mantle under the Antarctic Plate from surface wave tomography, Geophys. Res. Lett., 28, 4395-4398.

Holt, J. W. (2001), Airborne surveys conducted by SOAR for geologic studies in Antarctica, Eos Trans, AGU, 82(20), Spring Meet. Suppl., Abstract GP 42A-07.
Huerta, A. D., and D. L. Harry (2007), The transition from diffuse to focused extension: Modeled evolution of the West Antarctic Rift system, Earth Planet. Sci. Lett. 255, 133-147, doi: 10.1016/j.epsl.2006.12.011

Larson, A. M., A. Nyblade, D. Wiens, S. Anandakrishnan, T. Watson, M. Benoit, P. Shore and D. Voigt (2006), Results for the mantle transition zone beneath the Transantarctic Mountains from receiver functions, Eos Trans, AGU 87 (52) Fall Meet. Suppl.. Abstract S41A1310

Lawrence, J. F., D. A. Wiens, A. A. Nyblade, S. A. Anandakrishnan, P. J. Shore, and D. Voigt (2006a), Upper mantle thermal variations beneath the Transantarctic Mountains inferred from teleseismic Swave attenuation, Geophys. Res. Lett., 33, L03303, doi: 10.1029/2005GL024516.

Lawrence, J. F., D. A. Wiens, A. A. Nyblade, S. A. Anandakrishnan, P. J. Shore, and D. Voigt (2006b), Crust and upper mantle structure of the Transantarctic Mountains and surrounding regions from receiver functions, surface waves, and gravity: Implications for uplift models, Geochemistry, Geophysics Geosystems, 7, Q10011, doi: 10.1029/2006GC001282

Lawrence, J. F., D. A. Wiens, A. A. Nyblade, S. A. Anandakrishnan, P. J. Shore, and D. Voigt (2006c), Rayleigh wave phase velocity analysis of the ross Sea, Transantarctic Mountains, and East Antarctica, from a temporary seismograph array, J. Geophys. Res., 111, doi:10.1029/2005JB003812

Lythe, M. B., D. G. Vaughn, and BEDMAP consortium (2001), BEDMAP: A new ice thickness and subglacial topographic model of Antarctica, J. Geophys. Res., 106, 11,335-11,351.

Ritzwoller, M. H., N. M. Shapiro, A. L. Levshin, and G. M. Leahy (2001), Crustal and upper mantle structure beneath Antarctica and surrounding oceans, J. Geophys. Res., 106, 30,645-30,670.

Siegert, M. J., and J. A. Dowdeswell (1996), Spatial variations in heat at the base of the Antarctic ice sheet from analysis of the thermal regime above subglacial lakes, J. of Glaciology, 42(142), 501-509.

Sieminski, A., E. Debayle, and J. J. Leveque (2003), Seismic evidence for deep low-velocity anomalies in the transition zone beneath West Antarctica, Earth Planet. Sci. Lett., 216, 645-661.

Stern, T. A., and U. S. ten Brink (1989), Flexural uplift of the Transantarctic Mountains, J. Geophys. Res., 94, 10,315-10,330.

Studinger, M., R. E. Bell, W. R. Buck, G. D. Karner, and D. D. Blankenship (2004), Subglacial geology inland of the Transantarctic Mountains in light of new aerogeophysical data, Earth Planet. Sci. Lett., 220, 391-408.

Studinger, M., R. E. Bell, P. G. Fitzgerald, and W. R. Buck (2006), Crustal Architecture of the Transantarctic Mountains between the Scott and Reedy Glacier Region and South Pole from aerogeophysical data, Earth Planet. Sci. Lett., 250, 182-199.

Talwani, M., J. L. Worzel, and M. Landisman (1959), Rapid gravity computations for two-dimensional bodies with application to the Mendocino Submarine Fracture Zone, J. of Geophys. Res., 64, 49-61.

Telford, W. M., L. P. Geldart, and R. E. Sheriff (1990), Applied Geophysics, 770 p., Cambridge University Press.

ten Brink, U. S., R. I. Hackney, S. Bannister, T. A. Stern, and Y. Makovsky (1997), Uplift of the Transantarctic Mountains and the bedrock beneath the East Antarctic ice sheet, J. Geophys. Res., 102, 27,603-27,621.

ten Brink, U. S. and T. A. Stern (1992), Rift flank uplifts and hinterland basins: Comparison of the Transantarctic Mountains with the great escarpment of southern Africa, J. Geophys. Res., 97, 569-585.

van der Beek, P., S. Cloetingh, and P. Andriessen (1994), Mechanisms of extensional basin formation and vertical motions at rift flanks: constraints from tectonic modeling and fission track thermochronology, Earth Planet. Sci. Lett., 121, 417-433.

Watson, T., A. Nyblade, D. A. Wiens, S. Anandakrishnan, M. Benoit, P. J. Shore, D. Voigt, and J. VanDecar (2006), P and S velocity structure of the upper mantle beneath the Transantarctic Mountains, East Antarctic craton, and Ross Sea from travel time tomography, Geochem, Geophys, Geosyst., 7, Q07005, doi: 10.1029/2005GC001238. 